\title{
Paleoenvironmental Research in the Semiarid Lake Manyara Area, Northern Tanzania: A Synopsis
}

\author{
Felix Bachofer, Geraldine Quénéhervé, Christine Hertler, \\ Liane Giemsch, Volker Hochschild, and Michael Maerker
}

\begin{abstract}
The Lake Manyara area is the focus of several paleo-archeological investigations. The Manyara basin is located approximately $70 \mathrm{~km}$ east of Olduvai Gorge, where important paleoanthropological artifacts are traced back to Homo habilis. In the Manyara basin itself, two hominin-bearing sites $(0.78-0.633 \mathrm{Ma})$ and plenty of vertebrate bones and teeth as well as stone artifacts from different periods were discovered, especially close to the Makuyuni River. Different methodological approaches with a main emphasis on remote sensing were utilized to contribute to the understanding of the paleo-landscape development. In order to investigate the morphotectonic evolution of the study area, lineaments were detected from Synthetic Aperture Radar satellite scenes. The complex lacustrine development of the Lake Manyara and its paleo-stages was investigated by delineating the extent of paleo-lake sediments (older than $0.633 \mathrm{Ma}$ ) with multispectral ASTER data. In addition, lake terraces and shorelines on different levels (up to $80 \mathrm{~m}$ above today's lake level) and an outlet to the neighboring Engaruka basin were detected by analyzing the backscattered intensity of TerraSAR-X data. The distribution of topsoils, identified from multisensory remote sensing datasets, indicates soil formation as well as erosional and depositional processes. The fossils and artifacts were then
\end{abstract}

F. Bachofer $(\bowtie) \cdot$ G. Quénéhervé • V. Hochschild Institute of Geography, University of Tuebingen, Ruemelinstr. 19-23, 72070 Tuebingen,

Germany

e-mail: felix.bachofer@uni-tuebingen.de; geraldine.queneherve@uni-tuebingen.de; volker.hochschild@uni-tuebingen.de

C. Hertler

Heidelberg Academy of Sciences and Humanities, Ruemelinstr. 19-23, 72070 Tuebingen, Germany
Senckenberg Forschungsinstitut, Senckenberganlage 25, 60325 Frankfurt am Main, Germany

e-mail: christine.hertler@senckenberg.de

L. Giemsch

Archäologisches Museum Frankfurt, Karmelitergasse 1, 60311 Frankfurt am Main, Germany

e-mail: liane.giemsch@stadt-frankfurt.de

M. Maerker

Heidelberg Academy of Sciences and Humanities, Ruemelinstr. 19-23, 72070 Tuebingen, Germany e-mail: michael.maerker@uni-tuebingen.de 
characterized, and their distribution probabilities were determined using a statistical model. The proposed methods contribute to a better understanding of the paleoenvironmental interrelations within the study area.

\section{Keywords}

Paleolithic - Vertebrate fossils and fish bones - Landscape reconstruction • Site prediction $\bullet$ Stochastic modeling $\bullet \mathrm{SAR} \bullet$ Remote sensing $\bullet$ EARS

\subsection{Introduction and Study Area}

The East African Rift System (EARS) (Fig. 8.1) is perceived as a migration corridor linking eastern and southern Africa and providing potential ways "out of Africa" for early humans. In this context, we focus on the Northern Tanzanian section of the eastern branch of the EARS, the so-called Gregory Rift. As already stated by Leakey (1979) and numerous other authors, Tanzania is well known for prehistoric specimens of early hominids found, for example, in Olduvai Gorge, at Lake Masek or at Laetoli (Fig. 8.2). For the evolution of hominids and especially hominins, the EARS seems to be a crucial region. The geographic center of this study lies in the vicinity of Olduvai, yet within the half-graben of the Gregory Rift around the eastern margins of Lake Manyara and along the Makuyuni River. Lake Manyara (954 $\mathrm{m}$ a.s.l.) is located in an endorheic basin (Fig. 8.1) and is a shallow soda lake that periodically dries out completely (Deus et al. 2013). The primary structural unit of the Manyara basin is an asymmetrically shaped rift. To the west extends the 250-900 m high escarpment. A west-dipping monocline and the volcano Essimingor prevail in the east. The water supply originates from springs at the base of the rift escarpment and from several seasonal drainages (Schwartz et al. 2012).

Paleo-lake evidences, like paleo-shorelines, sediments, and fossils, were found by Jaeger (1913) and Reck (1921) to the east of Lake Manyara already in the beginning of the twentieth century. Pleistocene sequences in the valley of the Makuyuni River were discovered early on by Louis and Mary Leakey and were later examined by Kent in 1935 (Kent 1941, 1942). Keller and colleagues collected Pleistocene faunal material and Middle Stone Age (MSA) lithics and published several stratigraphic sections (Keller et al. 1975). Recent studies investigated the geology, paleontology, and archeology of the Lake Manyara Beds, e.g., Kaiser et al. (1995, 2010), Kaiser (2000), Ring et al. (2005a), Frost et al. (2012), Schwartz et al. (2012), Mana et al. (2012), and Giemsch (2015).

Previous studies have shown that two fossilbearing layers of different ages exist in the area, namely, the Lower and Upper Manyara Beds (UMB and LMB, respectively). Correlations with the sequence in Olduvai seem to indicate Lower and Middle Pleistocene ages for the Manyara Beds (Ring et al. 2005a; Frost et al. 2012; Schlüter 1987). Kaiser et al. (2010) show the corresponding stratigraphic succession. Upper terrestrial beds and lower lacustrine beds are separated by a clear boundary characterized by a color change from grayish (lacustrine sediments) to reddish (terrestrial deposits). The entire stratigraphy is interspersed with presumably reworked tuff deposits. Moreover, UMBs and LMBs bear fossil layers.

The large number of (fossil) bearing sites, including specimens of fossil vertebrates and artifacts, detected during various field campaigns of the authors from 2007 to 2014, was the motivation for a more extensive analysis of the spatial distribution of these sites, in relation to environmental characteristics and processes. Different methodological approaches, with a major emphasis on remote sensing, were utilized to contribute to the understanding of the paleo-landscape development and their relations in order to find assemblages. 


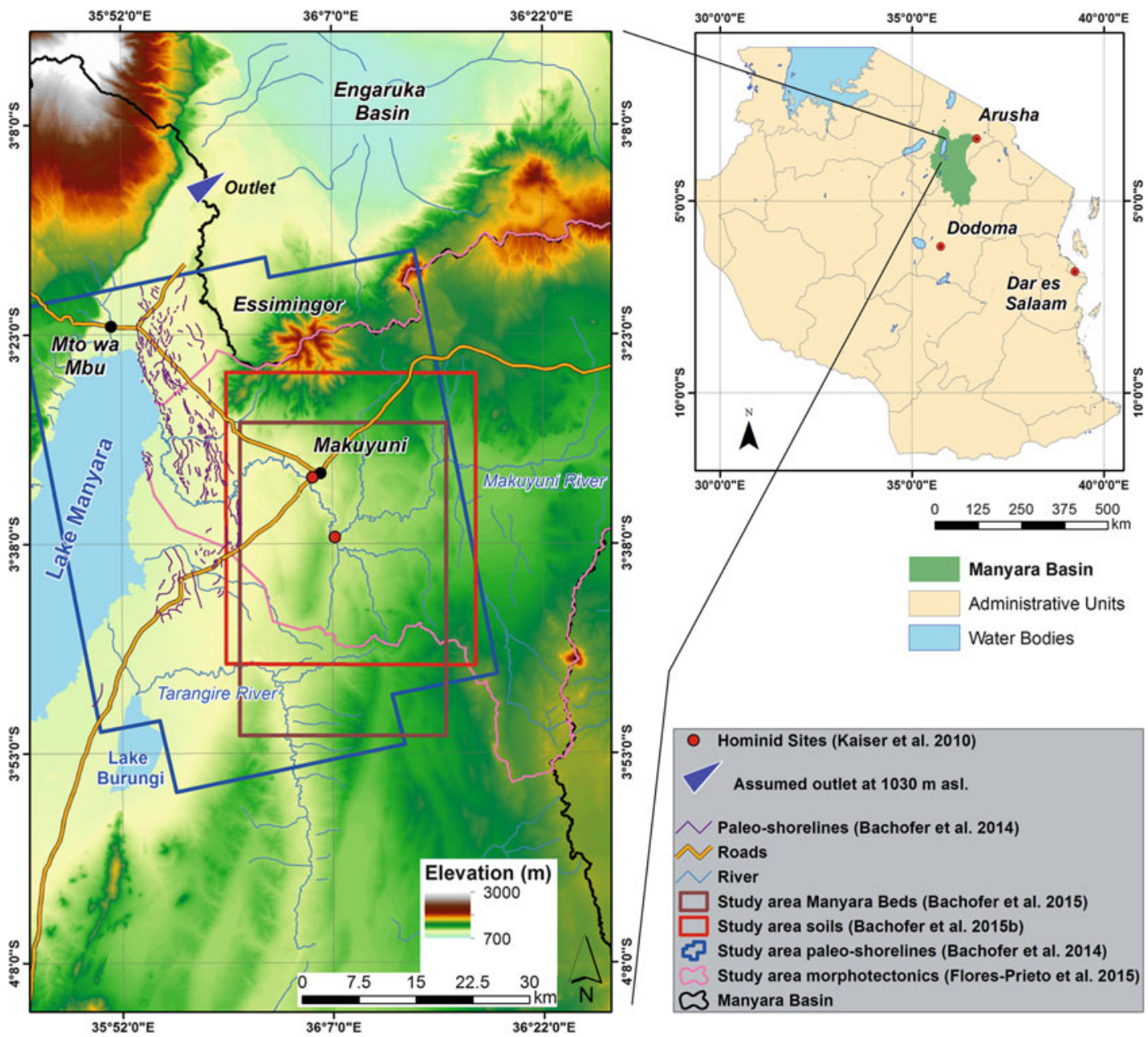

Fig. 8.1 The locations and extent of the study areas in the Lake Manyara basin in Northern Tanzania

We investigate the morphotectonic evolution of the study area, the complex lacustrine dynamics of the Lake Manyara, and its paleo-stages as well as the related lake terraces and shorelines at different levels (up to $80 \mathrm{~m}$ above today's lake level). Additionally, we study the distribution of topsoils and outcropping substrates to decipher soil formation processes as well as erosional and depositional processes. Finally, the fossils and artifacts were characterized, and the probability distributions were determined using a stochastic approach. The proposed methods contribute to a better understanding of the paleoenvironmental interrelations within the study area.

\subsection{Morphotectonics and Their Interpretation}

In the EARS, landforms are caused by effects of the active continental extension zone within the graben systems as well as by volcanic, erosional, and depositional processes. Tectonic processes formed the recent drainage systems and landforms. The tectonics of this region were previously studied in terms of (1) kinematic and structural geology (Ring et al. 2005b), (2) faulting, (3) Neogene tectonics and volcanism (Dawson 1992, 2008; Le Gall et al. 2008; Albaric et al. 2009), (4) and structural geology 


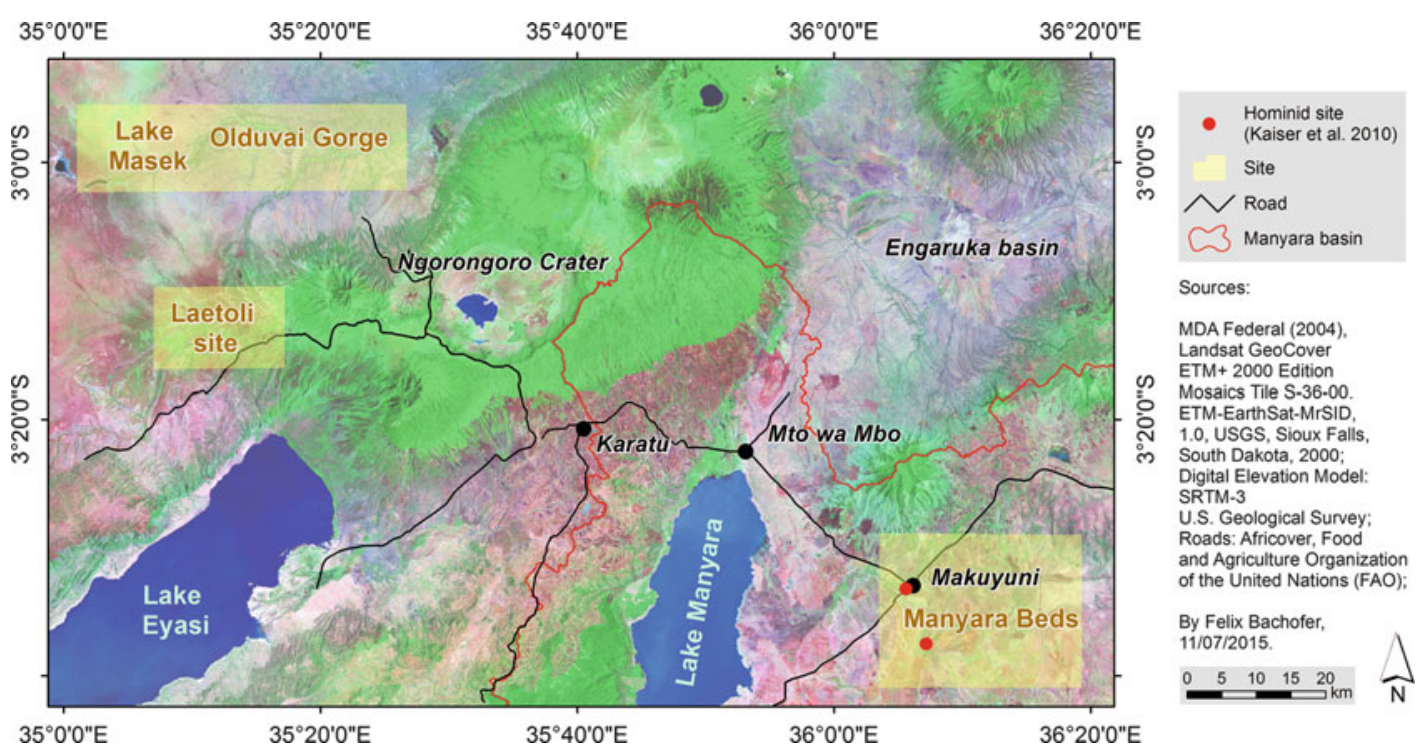

Fig. 8.2 Outlined sites of the Olduvai, Masek, Laetoli, and Manyara Beds, which comprise rich paleontological and archeological findings [with permission of Bachofer (2015)]

(Albaric et al. 2010). However, the link between landscape morphology and tectonics has yet to be directly addressed.

Drainage network, stream longitudinal profiles, basin analysis, and lineament extraction can be used as methods for identifying tectonic activity and related features in rift areas (FloresPrieto et al. 2015):

1. Relief and landscape patterns of the Lake Manyara basin reflect the evolution of a complex part of the rift systems that underwent combined effects of tectonic factors inherent to its geological settings and Quaternary geomorphological processes. In the Makuyuni catchment, lineaments were extracted from a Synthetic Aperture Radar (SAR) image (ENVISAT ASAR, 2011-08-02) (Fig. 8.3). They show an $\mathrm{N}-\mathrm{S}$ orientation and reveal tectonic activity characterized by deviations and knickpoints of streambeds and the occurrence of erosion processes.

2. Concavity and steepness values of drainage network segments depend on basin morphology, underlying rock strengths, and hydraulic geometry (Snyder et al. 2000). These values are especially used for evaluating river system responses to different landscape forming and modifying processes, including patterns of tectonic uplift and deformation (Wobus et al. 2006). The general increase of concavity and steepness values within drainage longitudinal profiles in the Makuyuni catchment indicates an uplift associated with tectonic activity.

3. A distinct base level of a landscape is related to an erosional stage and can be considered a product of erosional tectonic events (Golts and Rosenthal 1993). The development and migration of knickpoints due to changes in the base level can be related to lineament structures.

4. The morphology of the stream longitudinal profiles (Shahzad and Gloaguen 2011), basin tilting (Hare and Gardner 1985) and basin hypsometry (Pérez-Peña et al. 2009) suggest the importance of tectonic activity in governing Quaternary geomorphological processes, such as river incision and soil erosion, and hence, the landscape evolution of this region.

This analysis has allowed the differentiation of the Makuyuni catchment into two distinctive areas: (a) tectonic activity influences the hydrological controlled northern section, and (b) a more stable southern section, where the Precambrian lithology and less intense tectonics prove dominant. 


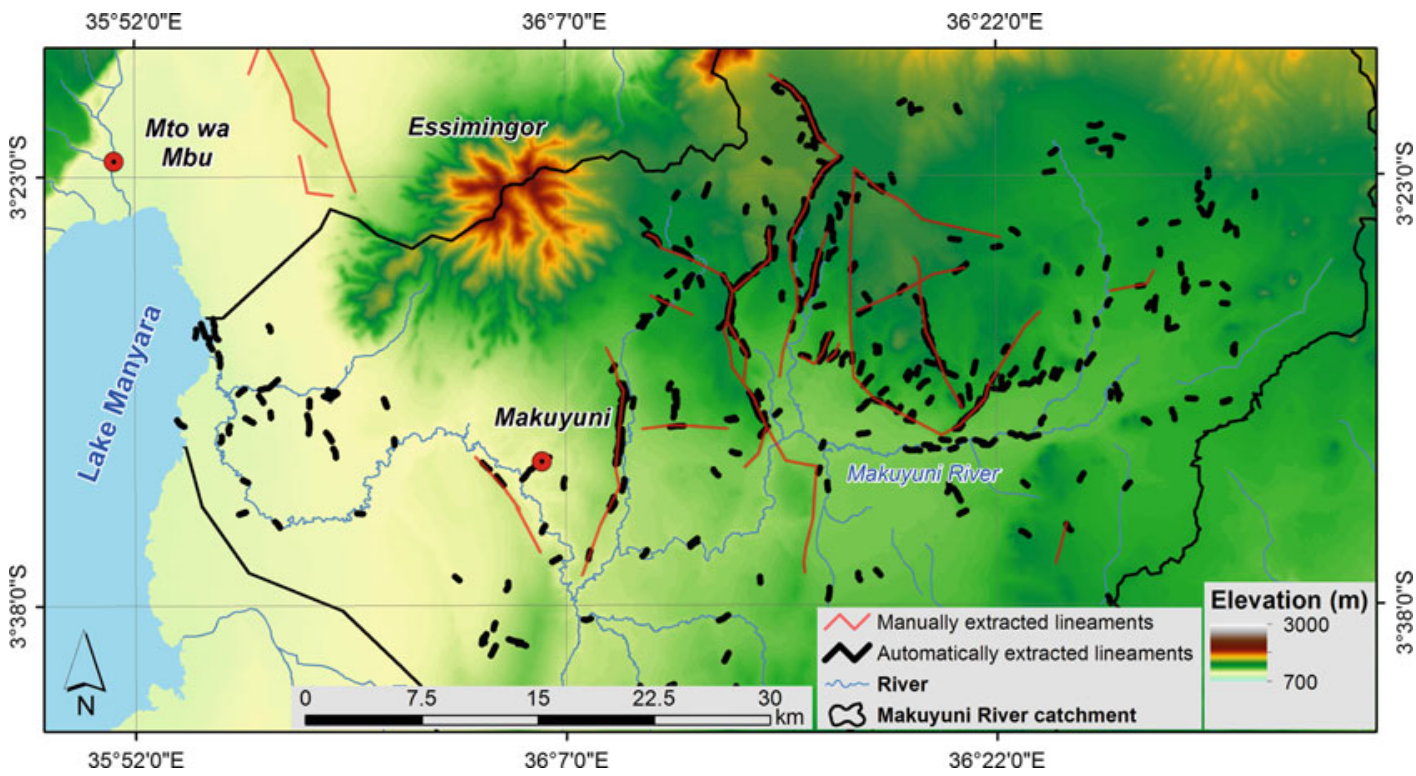

Fig. 8.3 Automatically and manually extracted lineaments

\subsection{Delineation of the Manyara Beds}

The stratigraphy of the Manyara Beds includes two fossil-bearing beds, namely, the LMBs and the UMBs (Schwartz et al. 2012). The UMB is composed of terrestrial deposits of up to $13 \mathrm{~m}$ mudstones, siltstones, conglomerates, and breccias. The deposition took place between $0.633 \mathrm{Ma}$ and $0.44(0.27) \mathrm{Ma}$ (Ring et al. 2005a; Schwartz et al. 2012). A distinct layer of tephra is situated at the transition of the UMB to the $\mathrm{LMB}$, which was ${ }^{40} \mathrm{Ar} /{ }^{39} \mathrm{Ar}$ dated to 0.633 Ma (Ring et al. 2005a; Schwartz et al. 2012). Schwartz et al. (2012) conclude, from assumed sedimentation rates, the beginning of the deposition of the LMBs between 1.3 Ma and $0.98 \mathrm{Ma}$. The Manyara Beds are underlain Precambrian intermediate gneisses in the south of the study area and by a sequence of nephelinitic conglomerates, nephelinitic lavas, and rocks in the vicinity of Essimingor, which have a minimum age of 1.4 Ma (Bagdasaryan et al. 1973). The LMB represents lacustrine deposits, grayish in color, and consist mainly of tuff, marls, siltstones, mudstones, and diatomite.
The LMBs indicate the maximum extent and highest level of Lake Manyara.

An ASTER multispectral satellite image (2006-08-23), and topographic information derived of a SRTM-X digital elevation model (DEM), was used as input datasets for the delineation of the Manyara Beds. The ASTER system is composed of a sensor for visible and nearinfrared wavelengths (VNIR: 0.52-0.86 $\mu \mathrm{m}$; $15 \mathrm{~m}$ ground resolution), a shortwave sensor (SWIR: 1.6-2.43 $\mu \mathrm{m}$; $30 \mathrm{~m}$ ground resolution), and a thermal infrared sensor (TIR: 8.125-11.65 $\mu \mathrm{m} ; 90 \mathrm{~m}$ ground resolution) (Fujisada 1995). For the bands of the VNIR and SWIR spectral region, 35 spectral indices were calculated (Bachofer et al. 2015). Spectral indices are ratios of distinct spectral bands emphasizing the presence or absence of vegetation and different mineral compositions. Twenty-five additional topographic indices were calculated from a SRTM-X DEM (Bachofer et al. 2015).

For the delineation of the specific stratigraphic layers of the Manyara Beds, we applied a support vector machine (SVM) classifier based on the library of support vector machines (LIBSVM) (Chang and Lin 2011). SVM is a 
supervised classification approach, which maximizes the margin for the input features (spectral and topographic indices), describing the intended target classes (UMB and LMB). For the optimization of margins between several input features, it is necessary to transfer the data into an $n$-dimensional feature space. Kernel functions are used to separate the independent input features by the target classes (Vapnik 1995, 1998). Four hundred ninety-eight ground reference points, which were collected in field campaigns, were used to train and validate the datasets. The UMB and LMB were identified with an overall accuracy (OA) of $80 \%$, when merely applying the SVMs to delineate the LMB 91\% OA were reached (Bachofer et al. 2015). The results exhibit the surface distribution of the LMB and UMB (Fig. 8.4). In the eastern part of the study area, lacustrine sediments were identified, which are similar to the LMB and bear also vertebrate fossils. Based on indications of previous research, due to the topographic position of these sediments, we propose the existence of a cascaded lake system parallel to an extended paleo-lake Manyara following the main faults toward the east.

\subsection{The Paleo-shorelines of Lake Manyara}

Paleo-shorelines and terraces result from different stages of quaternary lake-level high stands, which were already identified by various researchers in the early twentieth century (Uhlig 1909; Jaeger 1913; Leakey 1931). Certain shorelines were even mapped (Keller et al. 1975). The $14 \mathrm{C}$ and $\mathrm{Th} / \mathrm{U}$ dating of stromatolites of a distinct paleo-shoreline level helped in identifying different humid periods at $22 \mathrm{ka}$, 27-23 ka, 35-32 ka, $90 \mathrm{ka}$, and $140 \mathrm{ka}$ (Hillaire-Marcel et al. 1986; Casanova and Hillaire-Marcel 1992; Casanova 1986). The ages were supplemented by diatom analysis of two drilling cores in the Lake Manyara basin, which supported humid periods between 27.5-26 ka and 12.7-8 ka (Holdship 1976; Barker 1990; Goetz 1990) (Fig. 8.5). An

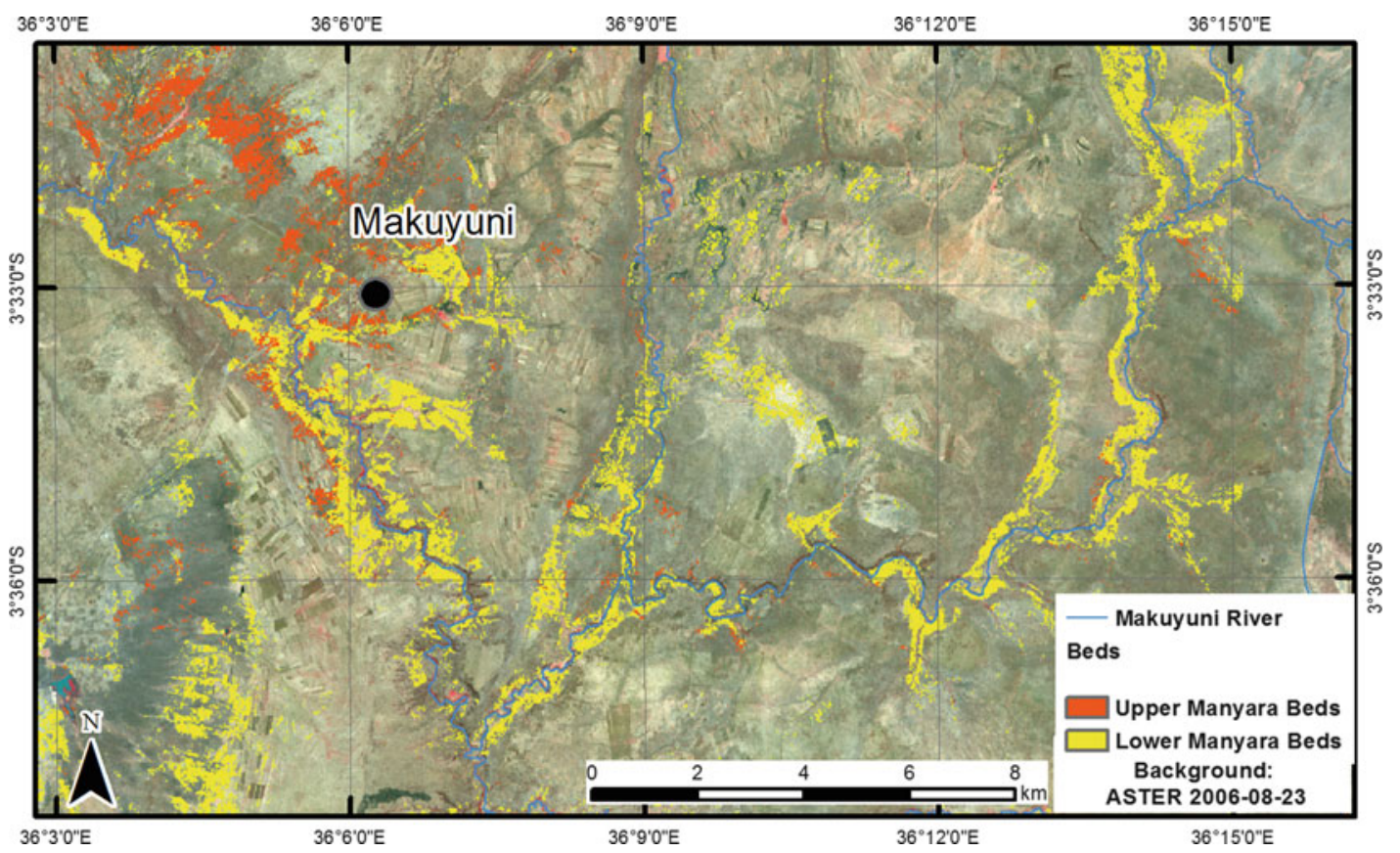

Fig. 8.4 Section with the classification result of UMB and LMB (based on ASTER and SRTM-X data) 


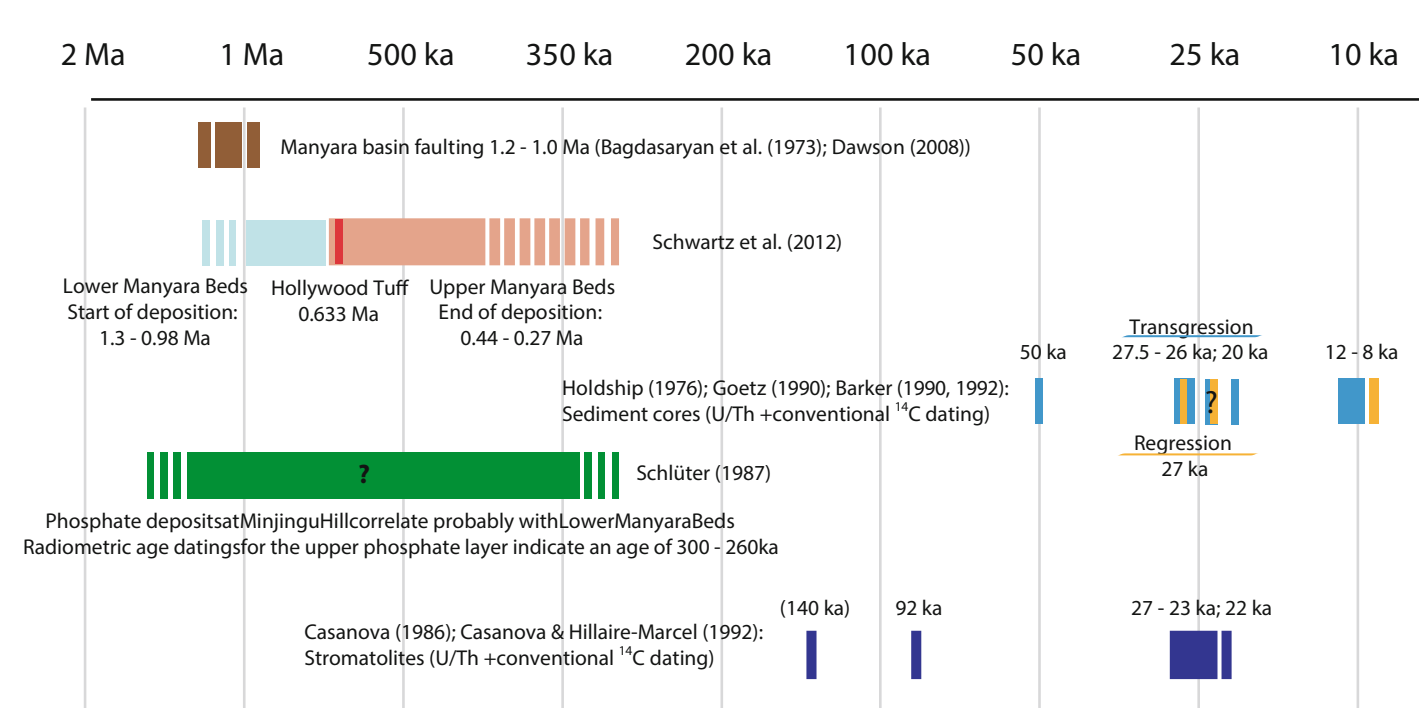

Fig. 8.5 Evidence for high paleo-lake levels in the Lake Manyara basin and basin faulting [with permission of Bachofer (2015)]

in-depth spatial consideration of the shorelines had thus far been missing.

Paleo-shorelines appear as small-scale landforms, which disappear in optical remote sensing images because of the uniform surface cover compared to their surroundings. A spectral analysis of the landforms proved to be difficult and led to unsatisfying results. Therefore, it was made use of the capabilities of SAR images. Most SAR systems are active remote sensing systems, which operate in the microwave electromagnetic spectrum. SAR systems transmit energy pulses and record the backscattered energy of objects (Lillesand et al. 2004). The backscattered signal is influenced mainly by the physical properties of a surface. In the case of paleo-shorelines and terraces, which occur as elongated steps and ridges, their geometry and the roughness of their coarse covering rocks led to an intense backscattered signal. The images from 2011 to 2013 were acquired by the TerraSAR-X satellite system (Bachofer et al. 2014). The scenes were radiometrically calibrated, and the paleoshorelines were delineated using a Canny edge operator (Canny 1986). For the edge analysis, the elevation was extracted of a SRTM-X digital elevation model. Several prominent paleo-lake levels were identified and validated with reference data from field surveys (Fig. 8.6) (Bachofer et al. 2014). The maximum lake level identified resembles an identical elevation to the lowest possible outlet of the endorheic Manyara basin (Fig. 8.6A). The position of the outlet indicates an overspill into the neighboring Engaruka and Natron-Magadi basins (Fig. 8.7).

\subsection{Lithosphere and Surface Soil Mapping}

The distribution of soils and rocks yields valuable information for the interpretation of landscape evolution. To acquire information regarding the surface characteristics, especially in areas with scarce vegetation cover, remote sensing techniques prove highly suitable.

During fieldwork and through laboratory analysis of surface soil samples, nine soil and lithological target classes were identified. As input datasets for the classification served (1) a high resolution WorldView-2 scene, (2) the backscattered intensity information of TerraSAR$\mathrm{X}$ and ENVISAT ASAR SAR images, (3) medium resolution ASTER spectral bands and corresponding spectral indices, as well as 


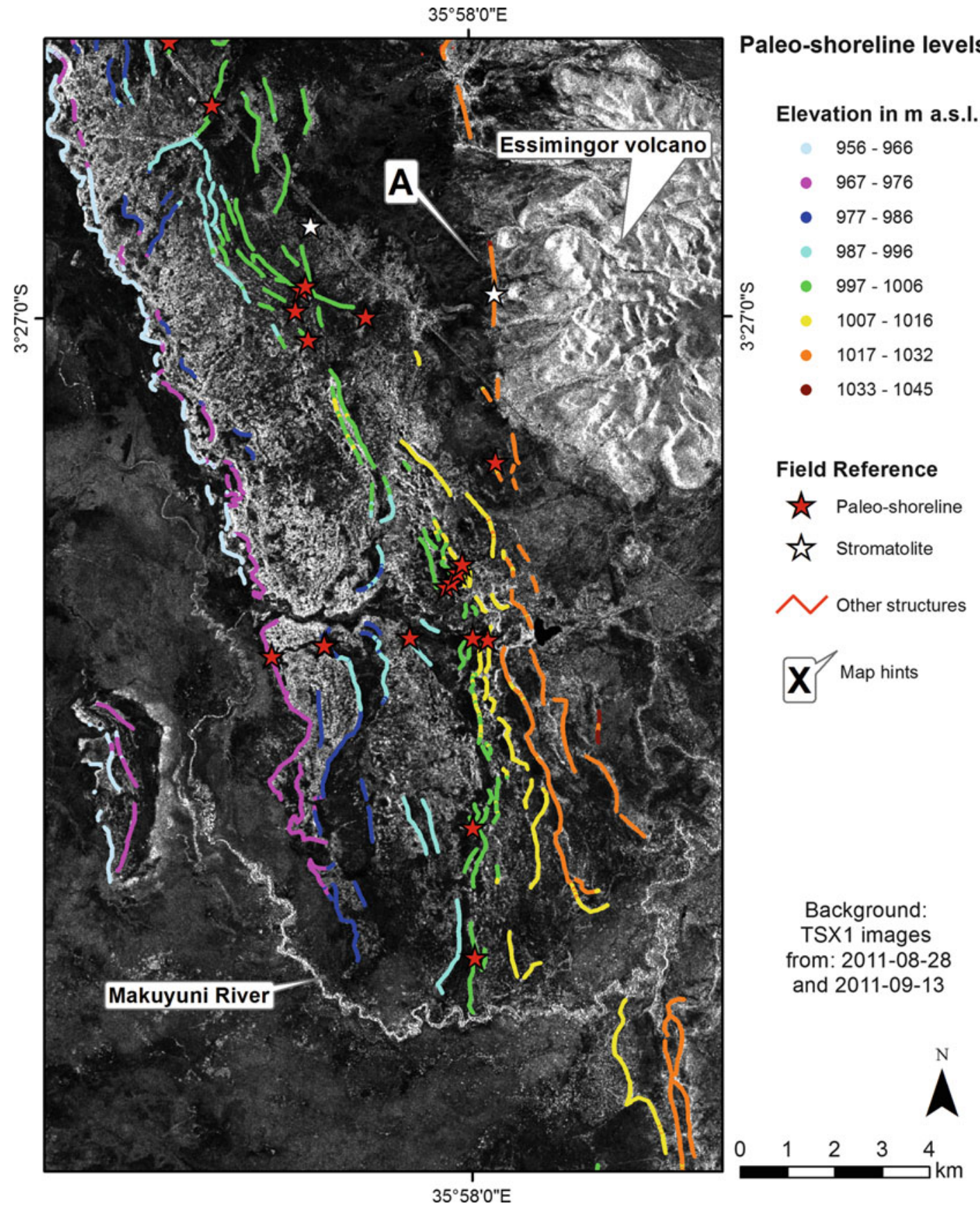

Fig. 8.6 Identified levels of paleo-shorelines after (Bachofer et al. 2014). The colors indicate different elevations of the paleo-shorelines. " $A$ " shows the highest

(4) SRTM-X-derived topographic indices. Because of the size of the input dataset, an image object segmentation was conducted to derive relative homogenous objects with the average value shoreline with more than $80 \mathrm{~m}$ above the present lake level. Stromatolites were found on this level

information of the underlying raster cells (Baatz and Schäpe 2000). Vegetated areas were excluded from further analysis by applying a normalized difference vegetation index (NDVI) threshold 

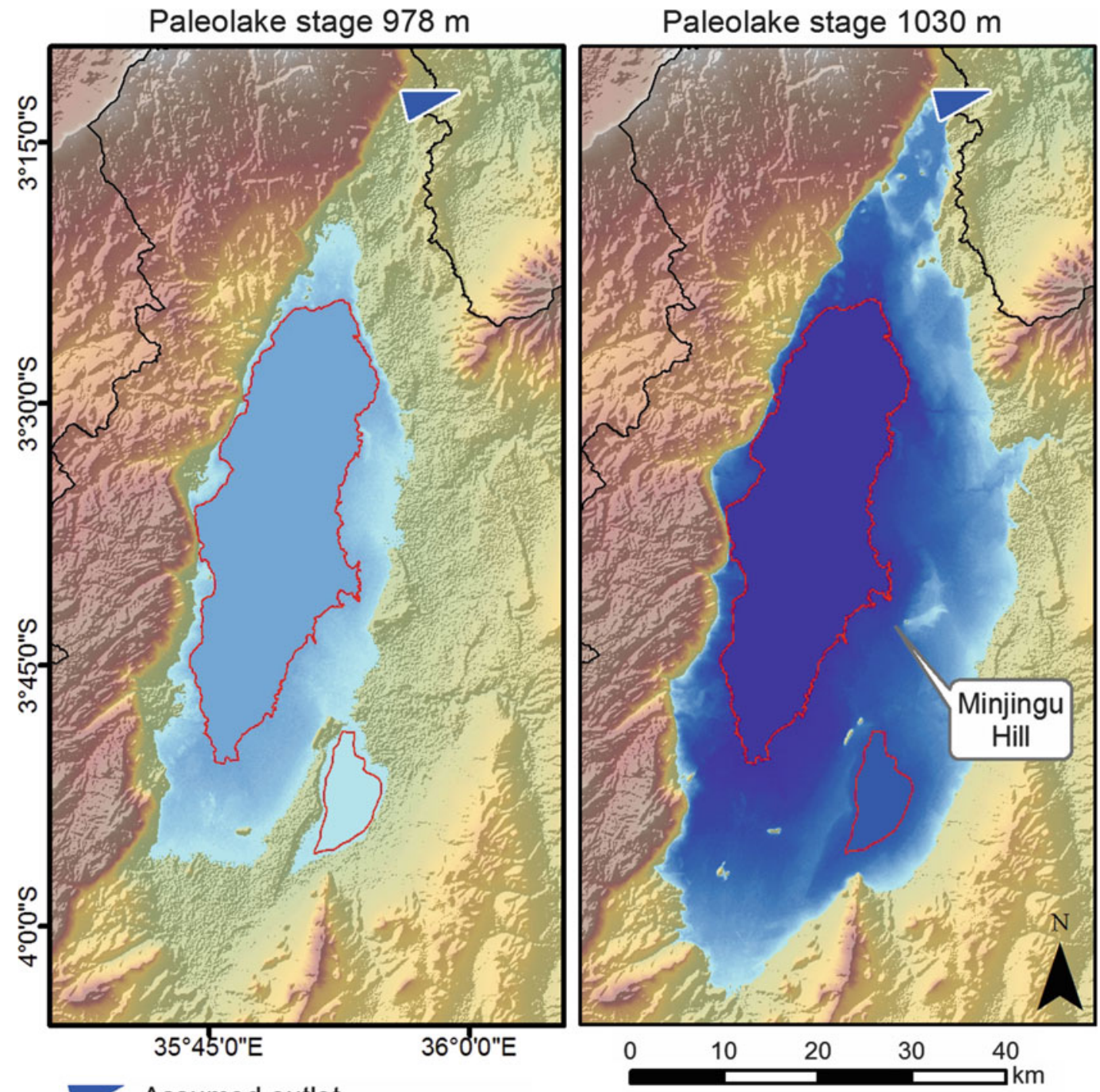

$\checkmark$ Assumed outlet

$\sum$ Watershed

Low: $0 \mathrm{~m}$

Paleolake depth in $\mathrm{m}$

3 Current maximum lake extent

Background: Shaded SRTM - DEM

Fig. 8.7 The paleo-lake levels for the Manyara basin at $978 \mathrm{~m}$ and $1030 \mathrm{~m}$

(Rouse et al. 1974). A nonlinear SVM approach was applied to classify the input dataset. Based on the spectral, physical, and topographical properties of the surface material, the nine target classes were identified with an overall accuracy of $71.9 \%$ (Fig. 8.8). By merging similar target classes such as "carbonate-rich sediments" and "calcaric topsoil," the accuracy could be increased significantly.

By means of recursive feature elimination (RFE), the features with the highest impact on the classification are identified (Guyon and Elisseeff 2003). The six most important input features are presented in Table 8.1. 


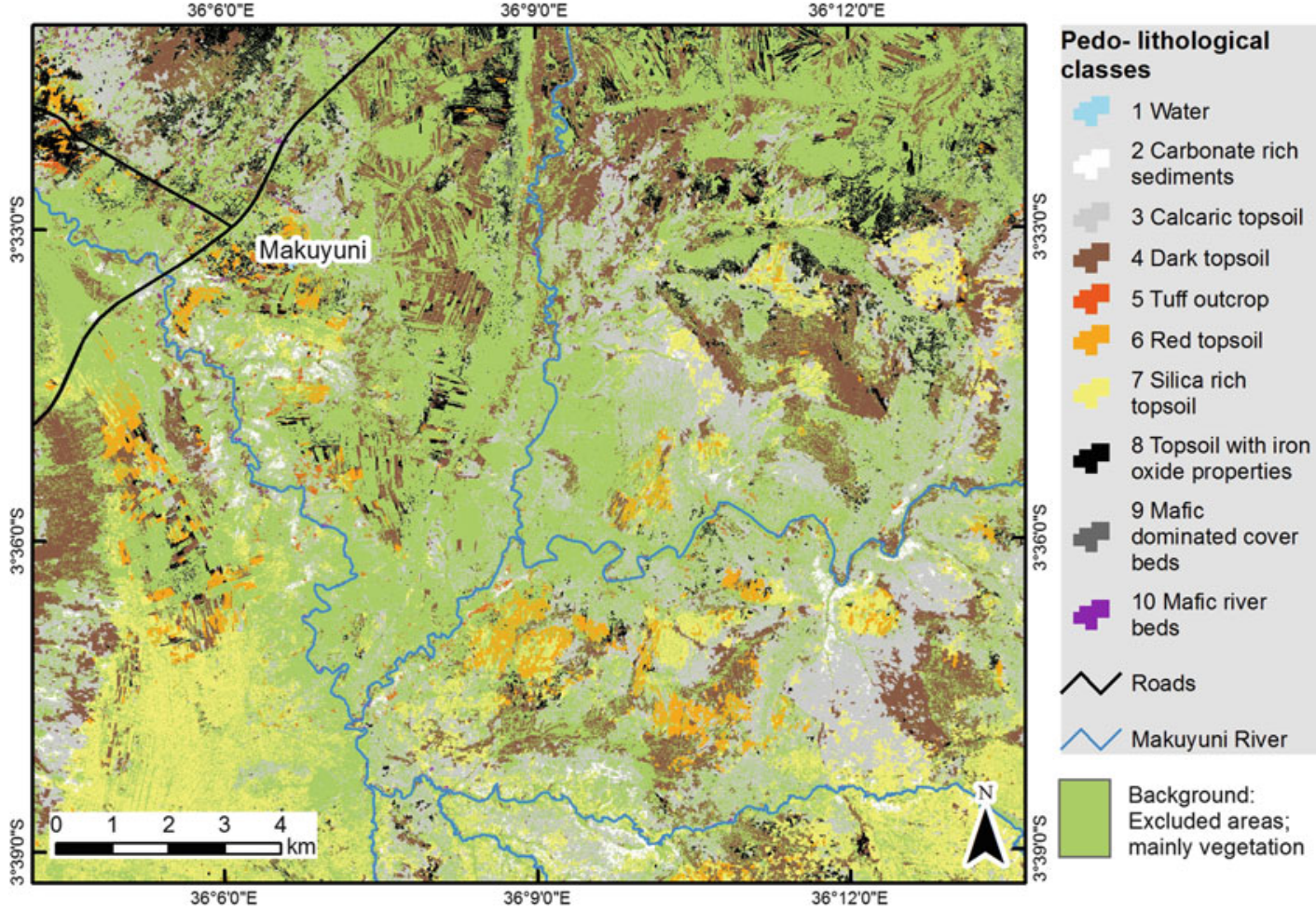

Fig. 8.8 Section of the pedo-lithological classification (based on WorldView-2, ASTER, TerraSAR-X, ENVISAT ASAR, and SRTM-X data)

Table 8.1 The six features with the highest impact on the classification identified by RFE

\begin{tabular}{l|l}
\hline Input feature & Type \\
\hline $\begin{array}{l}\text { Geomorphons (Jasiewicz and Stepinski } \\
\text { 2013) }\end{array}$ & $\begin{array}{l}\text { Topographic } \\
\text { index }\end{array}$ \\
\hline $\begin{array}{l}\text { Multiresolution index of ridge top } \\
\text { flatness (Gallant and Dowling 2003) }\end{array}$ & $\begin{array}{l}\text { Topographic } \\
\text { index }\end{array}$ \\
\hline WorldView-2 spectral band 3 (green) & Spectral band \\
\hline Ferric iron index (Mitchell et al. 2013) & Spectral index \\
\hline WorldView-2 spectral band 1 (coastal) & Spectral band \\
\hline Calcite index (Pour and Hashim 2011) & Spectral index \\
\hline
\end{tabular}

The results show that topsoils with iron oxide properties are predominant when associated with mafic outcrops of the slopes of the Essimingor volcano. "Carbonate-rich sediments" represent chiefly the LMBs, while "calcaric topsoil" indicates soil development processes upon the LMBs or on soils influenced by secondary carbonates. The thin outcrops of tuffs were identified at the stratigraphic border between the LMBs and UMBs. "Silica-rich topsoil" results from denudation processes on soils developed on the Proterozoic intermediate quartzite and gneisses of the Masai Plateau in the south of the study area.

\subsection{Archeological Settings and Site Prediction}

The large number of sites with specimens of fossil vertebrates and artifacts detected during different field campaigns was the motivation for a more thorough analysis of the spatial distribution of these sites in relation to present-day environmental characteristics and processes. Therefore, we developed an integrative spatial modeling concept using GIS, remote sensing, and sophisticated statistical methodologies 
based on statistical mechanics, e.g., MaxEnt (Jaynes 1957; Phillips et al. 2006). This method is able to handle presence-only datasets such as the locations proper.

The predictor variables consist of 50 continuous raster datasets applied in the modeling. The topographic indices characterize erosion transport and deposition processes as well as climatic and geologic variations in the landscape. They therefore not only reflect the immediate vicinity of a specific spot but additionally refer to a wider territorial context. Furthermore, we exploited spectral satellite data from the ASTER platform from which we calculated derivatives (spectral indices and band ratios) as predictor variables. Though most indices are designed for specific materials, they may also be used for a relative distinction between various minerals, depending on the abundant materials in the study area.

The target (also called response or dependent) variables consist in sites with paleontological evidence such as fossils or artifacts. In total, 102 sites were identified with differential GPS and transformed into point vector objects. Subsequently, we distinguished between archeological findings (stone artifacts only) from Early Stone Age (ESA) $\left(n_{\mathrm{A}}=45\right)$ and from Middle as well as Late Stone Age (MSA/LSA) $\left(n_{\mathrm{B}}=14\right)$ (Giemsch $2015)$ and for paleontological locations $\left(n_{\mathrm{C}}=43\right.$; fossils only).

The MaxEnt model predicts potential areas in which further fossil and/or artifact sites (paleontological sites) may be located. Figure 8.9 shows the areas with high potential in red to yellow and areas with low potential in dark blue. The research method considers not only site-specific characteristics but implicitly also the related pedogenetic and morphogenetic processes. The areas with high potential are mainly related to the paleodrainage network terraces and paleo-lake deposits.

In order to evaluate the model's predictive performance beyond classification matrices, we calculated the receiver operating characteristics (ROC) curve integral, also known as area under curve (AUC). Model performance is given by
AUC values of 0.95 for artifact sites and 0.90 for fossil sites.

The relative variable importance charts illustrate the overall importance of the salinity index (Al-Khaier 2003). The index relies on the ASTER bands four and five. This parameter may describe terrain elements with high salinity related to the former lake shores where salt concentration was high due to high salt contents of the lake itself and high evaporation rates of arid to semiarid paleoclimatic phases. The same bands can also be used to delineate soils with high iron content (Bierwirth 2002; Cudahy 2012). Other important ASTERderived parameters are the Burn Ratio (Hudak et al. 2004) as well as the Laterite index (Bierwirth 2002). The Burn Ratio is designed to highlight burned areas and however in our case correlates well with dark vertisols with sparse grass vegetation, which cover the lower river terraces and the $\mathrm{LMB} / \mathrm{UMB}$ transition. The Laterite index shows high iron contents present in the terrestrial tephra deposits. The DEM gives hints about the absolute elevation, in this case correlating with the former lake levels. The aspect, which is derived from the DEM, indicates the geological structure with main fault systems oriented from northwest to southeast.

Generally, the analysis shows that the paleontological sites are correlated mainly with the LMB/UMB transition and the paleo-river network. The results indicate the dependence of early hominids on water resources and food resources such as game, which also concentrates in these ecological units. However, the major difference between the paleontological sites and the ESA/MSA/LSA sites is related to general higher elevations where fossils occur. Moreover, the fossils seem to be related to stable paleolandscape features indicated by the quartz-rich rocks index (Rowan et al. 2005) and the Laterite index. In fact, the sites are mainly associated with cape rock material forming on lateritic paleo-soil horizons and outcrops of the felsic basement. The LS factor, a derivative of the DEM, points to a transport of the material by surface runoff (Moore et al. 1991). 

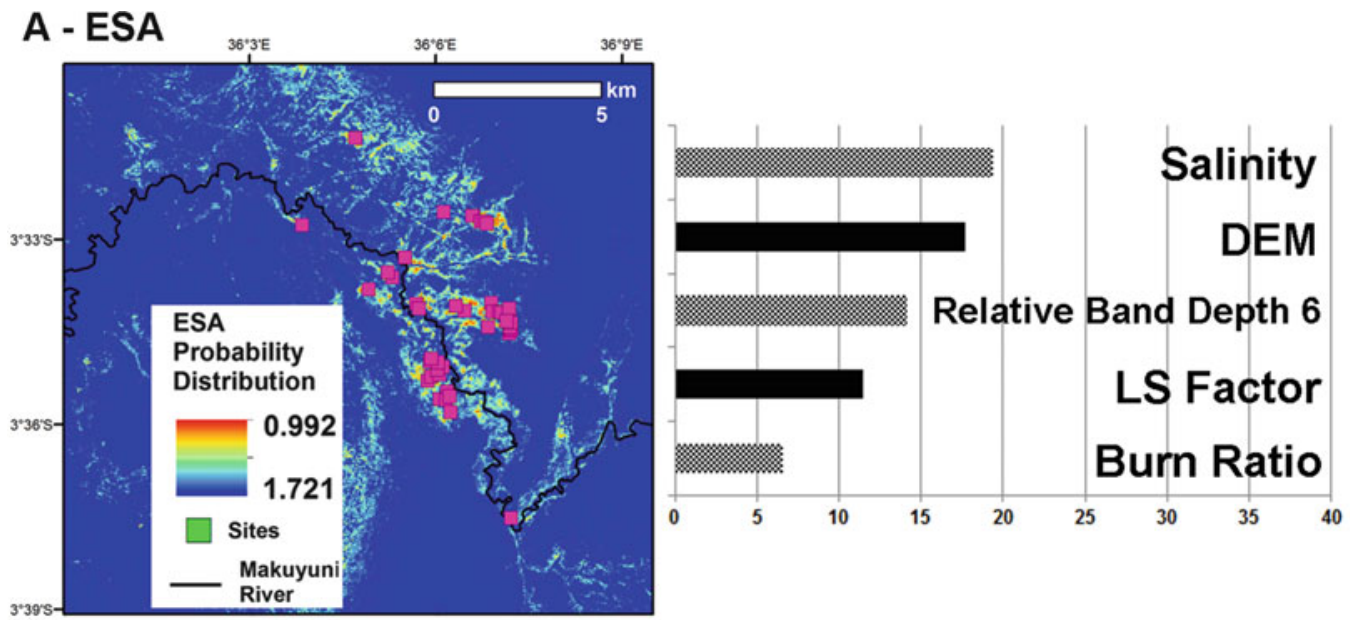

B - MSA/LSA
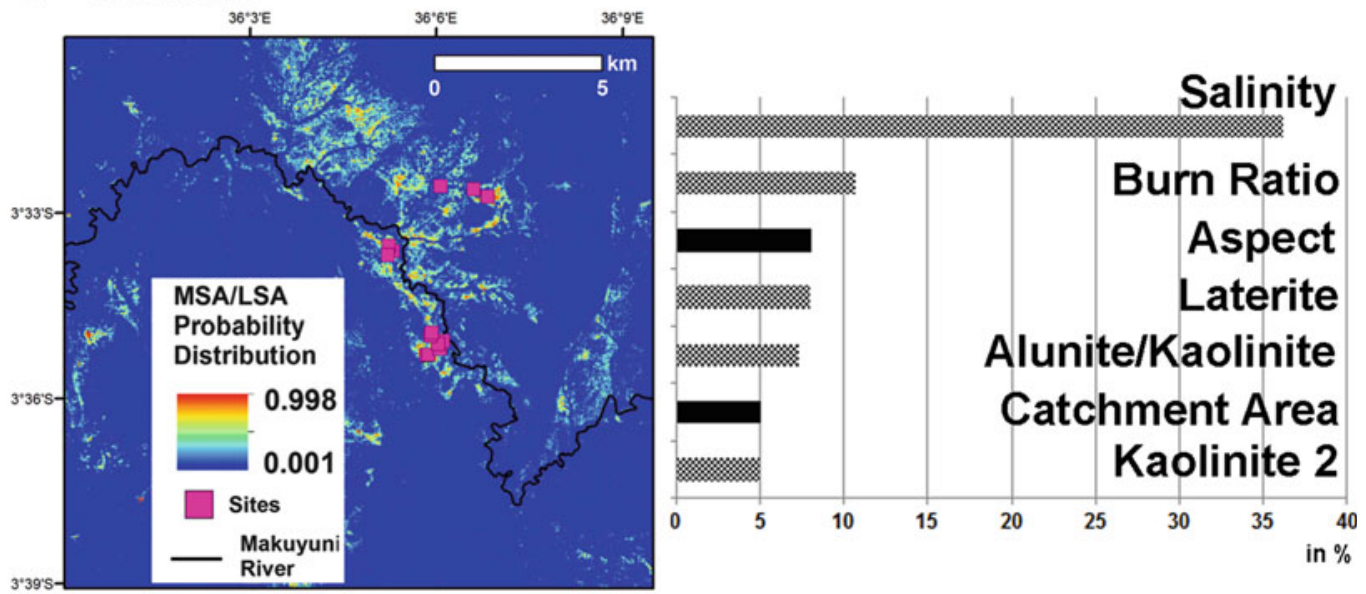

\section{C - Fossils}
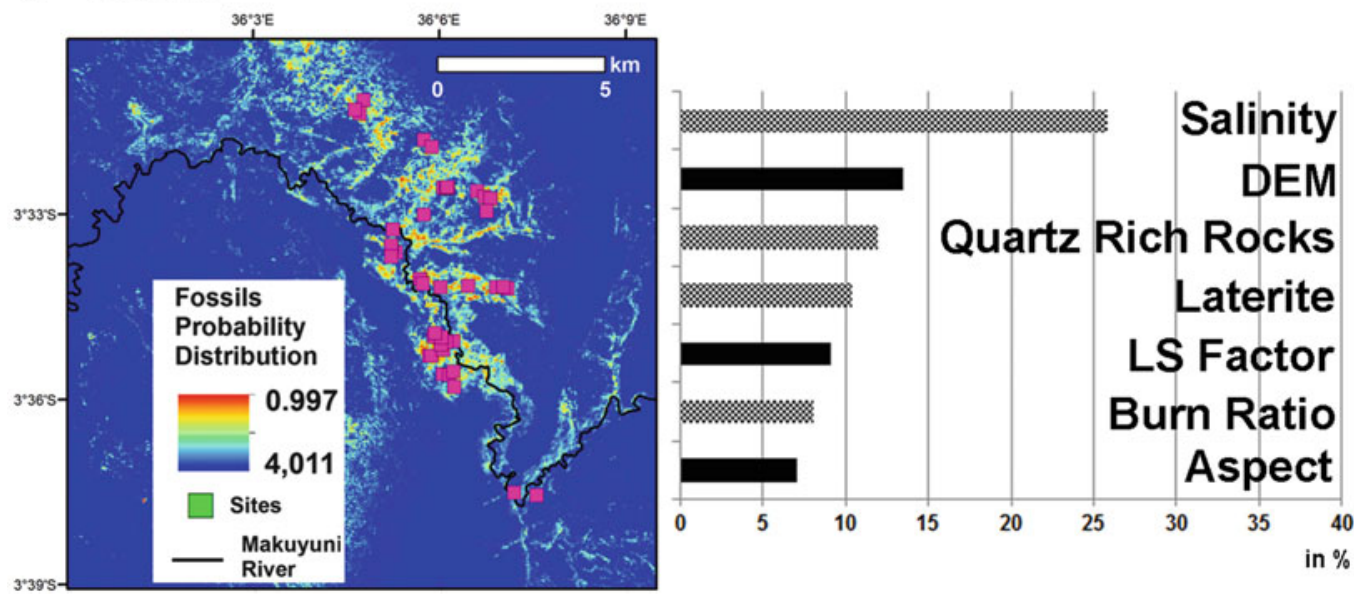

Fig. 8.9 Modeled probabilities and their variable importance in percentage for (a) Early Stone Age (ESA) artifacts, (b) Middle and Late Stone Age (MSA/LSA) artifacts, and (c) fossil sites 


\subsection{Conclusions}

The presented results from different digital geospatial methods draw a comprehensive picture of the landscape development in the Lake Manyara basin. Remote sensing data enabled area-wide analysis and interpretations. Attention should be paid on the individual contributions of remote sensing sensors. The application of SAR data and different optical sensors with high spatial and/or spectral resolution allowed a detailed analysis of present-day and paleo-landscape features. Stochastic- and machine-based learning algorithms provided insights into the driving factors concerning the spatial distribution of paleo-landscape features and find locations. In detail, we obtained the following results:

1. The analyses of morphotectonics of the Makuyuni catchment coupled with comprehensive research on topography, drainage networks, stream longitudinal profiles, and lineaments revealed a morphostructural control with an $\mathrm{N}-\mathrm{S}$ trend for the uplifted Masai Block, as well as tectonic deformation in the NE of the study area.

2. The Manyara Beds were identified, and evidence of lacustrine sediments further east of the study area has been detected. Besides a probable direct connection to the paleo-lake Manyara, it is also possible that parallel endorheic lacustrine and/or palustrine systems existed further east, which were subsequently cut and drained by the Makuyuni River.

3. The Lake Manyara underwent different transgression and regression phases during the abovementioned humid periods. The distinct morphological features of the paleoshorelines prove their extent on different elevations in the Lake Manyara basin. The most elevated shoreline proves an overspill into the Engaruka/Natron basins.

4. By analyzing a combination of remote sensing-derived surface characteristics and terrain features, the spatial distribution of topsoils and related soil types was derived. The results indicate a complex and heterogeneous evolution of the study area and of the Manyara basin as a whole. We identified strong relations between silica-rich topsoils and the Precambrian Masai Block, topsoils with iron oxide properties, and andosols on volcanic layers, as well as between carbonate-rich substrates and the Lower Manyara Beds.

5. We assessed the paleontological as well as archeological sites using stochastic models allowing also a prognosis of potential find locations. As shown, the highest potential is related to paleo-river network terraces and paleo-lake deposits. There are distinct differences between the fossil sites and the artifact sites. The latter seems to be closer to the paleo-shorelines and the paleo-river network, whereas the fossil sites seem to be related to cape rock formations in the higher parts of the fluvial terrace systems.

These above-summarized results have demonstrated the enormous potential of innovative remote sensing methods and statistical, machine-based learning algorithms to derive valuable information on paleo-landscape features on larger spatial scales. However, detailed fieldwork activity is required to properly calibrate and validate the proposed analyses.

Acknowledgments This study was funded by the Heidelberg Academy of Sciences and Humanities' research center "The Role of Culture in Early Expansions of Humans (ROCEEH)." The WorldView-2 scene is courtesy of the DigitalGlobe Foundation. We would like to thank the DLR and the German Remote Sensing Data Center (DFS) for providing the TerraSAR-X and the SRTM/X-SAR data. The ASTER L1B data were obtained through the online data pool at the NASA Land Processes Distributed Active Archive Center (LP DAAC), USGS/ Earth Resources Observation, and Science (EROS) Center, Sioux Falls, South Dakota, USA.

\section{References}

Albaric J, Déverchère J, Petit C, Perrot J, Le Gall B (2009) Crustal rheology and depth distribution of earthquakes: insights from the central and southern East African Rift System. Tectonophysics 468(1-4):28-41. https://doi. org/10.1016/j.tecto.2008.05.021 
Albaric J, Perrot J, Déverchère J, Deschamps A, Le Gall B, Ferdinand RW, Petit C, Tiberi C, Sue C, Songo M (2010) Contrasted seismogenic and rheological behaviours from shallow and deep earthquake sequences in the North Tanzanian Divergence, East Africa. J Afr Earth Sci 58(5):799-811. https://doi.org/ 10.1016/j.jafrearsci.2009.09.005

Al-Khaier F (2003) Soil salinity detection using satellite remote sensing. M.Sc. thesis, ITC Enschede, Enschede, Netherlands

Baatz M, Schäpe A (2000) Multiresolution segmentation: an optimization approach for high quality multi-scale image segmentation. In: Paper presented at the Angewandte Geographische Informationsverarbeitung XII. Beiträge zum AGIT-Symposium Salzburg

Bachofer F (2015) Assessment of paleo-landscape features using advanced remote sensing techniques, modelling and GIS methods in the Lake Manyara Basin, Northern Tanzania. Dissertation, University of Tuebingen, Tuebingen, Germany

Bachofer F, Quénéhervé G, Märker M (2014) The delineation of paleo-shorelines in the Lake Manyara Basin using TerraSAR-X Data. Remote Sens 6 (3):2195-2212. https://doi.org/10.3390/rs6032195

Bachofer F, Quénéhervé G, Märker M, Hochschild V (2015) Comparison of SVM and boosted regression trees for the delineation of lacustrine sediments using multispectral ASTER Data and topographic indices in the Lake Manyara Basin. Photogrammetrie, Fernerkundung, Geoinformation (PFG) 1/2015:81-94. doi:10.1127/pfg/2015/0251

Bagdasaryan G, Gerasimovskiy V, Polyakov A, Gukasyan R, Vernadskiy V (1973) Age of volcanic rocks in the rift zones of East Africa. Geochem Int 10:66-71

Barker PA (1990) Diatoms as palaeolimnological indicators: a reconstruction of Late Quaternary environments in two East African salt lakes. Dissertation, Loughborough University of Technology, Loughborough, UK

Bierwirth P (2002) Evaluation of ASTER satellite data for geological applications. Consultancy Report to Geoscience Australia

Canny J (1986) A computational approach to edge detection. IEEE Trans Pattern Anal Mach Intell 8(6):679-698. https://doi.org/10.1109/tpami.1986. 4767851

Casanova J (1986) Les stromatolites continentaux: paléoécologie, paléohydrologie, paléoclimatologie. Application au Rift Gregory. Dissertation, Université Aix-Marseille - II

Casanova J, Hillaire-Marcel C (1992) Chronology and paleohydrology of late quaternary high lake levels in the Manyara basin (Tanzania) from isotopic data (18O, 13C, 14C, ThU) on fossil stromatolites. Quat Res 38(2):205-226. https://doi.org/10.1016/00335894(92)90057-p
Chang C-C, Lin C-J (2011) LIBSVM: a library for support vector machines. ACM Trans Intell Syst Technol 2(3):1-27. https://doi.org/10.1145/1961189.1961199

Cudahy T (2012) Satellite ASTER geoscience product notes for Australia. CSIRO, Australia

Dawson JB (1992) Neogene tectonics and volcanicity in the North Tanzania sector of the Gregory Rift Valley: contrasts with the Kenya sector. Tectonophysics 204 (1-2):81-92. https://doi.org/10.1016/0040-1951(92) 90271-7

Dawson JB (2008) The Gregory rift valley and Neogenerecent volcanoes of Northern Tanzania. Geological Society Memoir 33. Geological Society, London. doi:https://doi.org/10.1144/M33

Deus D, Gloaguen R, Krause P (2013) Water balance modeling in a semi-arid environment with limited in situ data using remote sensing in Lake Manyara, East African Rift, Tanzania. Remote Sens 5(4):1651-1680 Flores-Prieto E, Quénéhervé G, Bachofer F, Shahzad F, Maerker M (2015) Morphotectonic Interpretation of the Makuyuni Catchment in Northern Tanzania using DEM and SAR data. Geomorphology 248:427-439. https://doi.org/10.1016/j.geomorph.2015.07.049

Frost SR, Schwartz HL, Giemsch L, Morgan LE, Renne PR, Wildgoose M, Saanane C, Schrenk F, Harvati K (2012) Refined age estimates and Paleoanthropological investigation of the Manyara Beds, Tanzania. J Anthropol Sci 90:151-161. https://doi.org/10.4436/ jass. 90001

Fujisada H (1995) Design and performance of ASTER instrument. In: Paper presented at the Proceedings of SPIE: advanced and next-generation satellites, Paris, France, 25 Sept 1995

Gallant JC, Dowling TI (2003) A multiresolution index of valley bottom flatness for mapping depositional areas. Water Resour Res 39(12):1347. https://doi.org/10. 1029/2002WR001426

Giemsch L (2015) Makuyuni; Fundstellen des Acheuléen am Lake Manyara, Tansania. Ein Beitrag zur Erforschung der mittelpleistozänen Kultur in Ostafrika, vol 7. Tübinger Arbeiten zur Urgeschichte. Verlag Marie Leidorf GmbH, Rahden, Germany

Goetz C (1990) Traçage isotopique et chronologie des processus d'altération et de sédimentation par l'étude des déséquilibres $U$ \& Th: application aux systèmes lacustres de Magadi (Kenya) et Manyara (Tanzanie). Dissertation, Universite Aix-Marseille II [S.1.]

Golts S, Rosenthal E (1993) A morphotectonic map of the northern Arava in Israel, derived from isobase lines. Geomorphology 7(4):305-315. https://doi.org/10. 1016/0169-555X(93)90060-F

Guyon I, Elisseeff A (2003) An introduction to variable and feature selection. J Mach Learn Res 3:1157-1182

Hare PW, Gardner T (1985) Geomorphic indicators of vertical neotectonism along converging plate margins, Nicoya Peninsula, Costa Rica. In: Morisawa M, Hack J (eds) Tectonic geomorphology. Allen and Unwin, Boston, MA, pp 75-104 
Hillaire-Marcel C, Carro O, Casanova J (1986) 14C and ThU dating of Pleistocene and Holocene stromatolites from East African paleolakes. Quat Res 25 (3):312-329. https://doi.org/10.1016/0033-5894(86) 90004-9

Holdship SA (1976) The paleolimnology of Lake Manyara, Tanzania: a diatom analysis of a 56 meter sediment core: a diatom analysis of a 56 meter sediment core. Dissertation, Duke University

Hudak AT, Robichaud P, Evans JS, Clark J, Lannom K, Morgan P Stone C (2004) Field validation of Burned Area Reflectance Classification (BARC) products for post fire assessment. In: Greer JD (ed) Remote sensing for field users; proceedings of the tenth Forest Service remote sensing applications conference, Salt Lake City, UT, April 5-9 2004. vol Paper 220. American Society of Photogrammetry and Remote Sensing, p 12

Jaeger F (1913) Das Hochland der Riesenkrater und die umliegenden Hochländer Deutsch-Ostafrikas; 2 Länderkundliche Beschreibung. Mitteilungen aus den deutschen Schutzgebieten/Ergänzungshefte; 8. Mittler, Berlin

Jasiewicz J, Stepinski TF (2013) Geomorphons - a pattern recognition approach to classification and mapping of landforms. Geomorphology 182:147-156. https://doi. org/10.1016/j.geomorph.2012.11.005

Jaynes ET (1957) Information theory and statistical mechanics. Phys Rev 106(4):620-630

Kaiser TM (2000) Die Taphonomie plio-pleistozäner Hominidenfundstellen Ostafrikas mit besonderer Berücksichtigung der Säugetierfaunen des Laetoliund Lake Manyara-Gebietes in Nordtansania. Archäologische Informationen 23(1):139-142

Kaiser T, Bromage TG, Schrenk F (1995) Hominid Corridor Research Project update: New Pliocene fossil localities at Lake Manyara and putative oldest Early Stone Age occurrences at Laetoli (Upper Ndolanya Beds), Northern Tanzania. J Hum Evol 28 (1):117-120. https://doi.org/10.1006/jhev.1995.1010

Kaiser TM, Seiffert C, Hertler C, Fiedler L, Schwartz HL, Frost SR, Giemsch L, Bernor RL, Wolf D, Semprebon G, Nelson SV, Schrenk F, Harvati K, Bromage TG, Saanane C (2010) Makuyuni, a new Lower Palaeolithic Hominid Site in Tanzania. Mitteilungen Hamburgisches Zoologisches Museum und Institut 106:69-110

Keller CM, Hansen C, Alexander CS (1975) Archaeology and paleoenvironments in the Manyara and Engaruka Basins, Northern Tanzania. Geogr Rev 65(3):364-376

Kent PE (1941) The recent history and pleistocene deposits of the plateau north of Lake Eyasi, Tanganyika. Geol Mag 78(03):173-184. https://doi. org/10.1017/S0016756800071867

Kent PE (1942) A note on pleistocene deposits near Lake Manyara, Tanganyika. Geol Mag 79(01):72-77. https://doi.org/10.1017/S0016756800073532

Le Gall B, Nonnotte P, Rolet J, Benoit M, Guillou H, Mousseau-Nonnotte $\mathrm{M}$, Albaric $\mathrm{J}$, Deverchère $\mathrm{J}$ (2008) Rift propagation at craton margin.
Tectonophysics 448(1-4):1-19. https://doi.org/10. 1016/j.tecto.2007.11.005

Leakey LSB (1931) East African Lakes. Geogr J 77 (6):497-508. https://doi.org/10.2307/1785041

Leakey MD (1979) Olduvai Gorge: my search for early man. Collins, London

Lillesand TM, Kiefer RW, Chipman JW (2004) Remote sensing and image interpretation, 5th edn. Wiley, New York

Mana S, Furman T, Carr MJ, Mollel GF, Mortlock RA, Feigenson MD, Turrin BD, Swisher CC (2012) Geochronology and geochemistry of the Essimingor volcano: melting of metasomatized lithospheric mantle beneath the North Tanzanian Divergence zone (East African Rift). Lithos 155:310-325. https://doi.org/10. 1016/j.lithos.2012.09.009

Mitchell J, Shrestha R, Moore-Ellison C, Glenn N (2013) Single and multi-date Landsat classifications of basalt to support soil survey efforts. Remote Sens 5 (10):4857-4876

Moore ID, Grayson RB, Ladson AR (1991) Digital terrain modelling: a review of hydrological, geomorphological, and biological applications. Hydrol Process 5 (1):3-30. https://doi.org/10.1002/hyp.3360050103

Pérez-Peña JV, Azañón JM, Azor A (2009) CalHypso: an ArcGIS extension to calculate hypsometric curves and their statistical moments. Applications to drainage basin analysis in SE Spain. Comput Geosci 35(6):1214-1223. https://doi.org/10.1016/j.cageo.2008.06.006

Phillips SJ, Anderson RP, Schapire RE (2006) Maximum entropy modeling of species geographic distributions. Ecol Model 190(3-4):231-259. https://doi.org/10. 1016/j.ecolmodel.2005.03.026

Pour AB, Hashim M (2011) Application of advanced spaceborne thermal emission and reflection radiometer (ASTER) data in geological mapping. Int J Phys Sci 6(33):7657-7668

Reck H (1921) Eine neue diluviale Säugetierfundstelle am Minjonjo in Deutsch-Ostafrika. Sitzungsberichte der Gesellschaft Naturforschender Freunde zu Berlin 1-3:25-36

Ring U, Schwartz HL, Bromage TG, Sanaane C (2005a) Kinematic and sedimentological evolution of the Manyara Rift in Northern Tanzania, East Africa. Geol Mag 142(4):355-368. https://doi.org/10.1017/ s0016756805000841

Ring UWE, Schwartz HL, Bromage TG, Sanaane C (2005b) Kinematic and sedimentological evolution of the Manyara Rift in Northern Tanzania, East Africa. Geol Mag 142(04):355. https://doi.org/10.1017/ s0016756805000841

Rouse JW, RH Haas, JA Shell, DW Deering and JC Harlan (1974) Monitoring the vernal advancement of retrogradation of natural vegetation. Final report, type III. NASA/GSFC, Greenbelt, MD

Rowan LC, Mars JC, Simpson CJ (2005) Lithologic mapping of the Mordor, NT, Australia ultramafic complex by using the Advanced Spaceborne Thermal Emission and Reflection Radiometer (ASTER). 
Remote Sens Environ 99(1-2):105-126. https://doi. org/10.1016/j.rse.2004.11.021

Schlüter T (1987) Paleoenvironment of lacustrine phosphate deposits at Minjingu, Northern Tanzania, as indicated by their fossil record. In: Matheis G, Schandelmeier $\mathrm{H}$ (eds) Current research in African earth sciences. Berlin, pp 223-226

Schwartz H, Renne PR, Morgan LE, Wildgoose MM, Lippert PC, Frost SR, Harvati K, Schrenk F, Saanane C (2012) Geochronology of the Manyara Beds, Northern Tanzania: new tephrostratigraphy, magnetostratigraphy and 40Ar/39Ar ages. Quat Geochronol 7:48-66. https://doi.org/10.1016/j.quageo.2011.09.002

Shahzad F, Gloaguen R (2011) TecDEM: A MATLAB based toolbox for tectonic geomorphology. Part 1: Drainage network preprocessing and stream profile analysis. Comput Geosci 37(2):250-260. https://doi. org/10.1016/j.cageo.2010.06.008

Snyder NP, Whipple KX, Tucker GE, Merritts DJ (2000) Landscape response to tectonic forcing: digital elevation model analysis of stream profiles in the Mendocino triple junction region, northern California. Geol Soc Am Bull 112(8):1250-1263. https://doi.org/10.1130/0016-7606(2000)112<1250: lrttfd $>2.0 . \mathrm{co} ; 2$

Uhlig C (1909) Die Ostafrikanische Bruchstufe und die angrenzenden Gebiete zwischen den Seen Magad und Lawa ja Mweri sowie dem Westfuß des Meru. Mitteilungen aus den deutschen Schutzgebieten/ Ergänzungshefte; 2. Mittler, Leipzig

Vapnik VN (1995) The nature of statistical learning theory. Springer, New York

Vapnik VN (1998) Statistical learning theory. Adaptive and learning systems for signal processing, communications, and control. Wiley, New York

Wobus C, Whipple KX, Kirby E, Snyder N, Johnson J, Spyropolou K, Crosby B, Sheehan D (2006) Tectonics from topography: procedures, promise, and pitfalls. Geol Soc Am Spec Pap 398:55-74. https://doi.org/ $10.1130 / 2006.2398(04)$

Open Access This chapter is licensed under the terms of the Creative Commons Attribution 4.0 International License (http://creativecommons.org/licenses/by/4.0/), which permits use, sharing, adaptation, distribution and reproduction in any medium or format, as long as you give appropriate credit to the original author(s) and the source, provide a link to the Creative Commons license and indicate if changes were made.

The images or other third party material in this chapter are included in the chapter's Creative Commons license, unless indicated otherwise in a credit line to the material. If material is not included in the chapter's Creative Commons license and your intended use is not permitted by statutory regulation or exceeds the permitted use, you will need to obtain permission directly from the copyright holder.

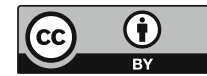

